London Museum. According to a report of the work to date which appears in the Times of August 10, it has now become evident that a building unearthed by Mr. A. Cunnington in 1882 and again brought to light by the present operations is a temple and not a villa as was at first believed. It is a Roman building which can be definitely identified as the type of temple peculiar to the Celtic regions of France, Germany and Great Britain during the Roman period. It was square in plan with a raised central shrine and a surrounding verandah. Behind the temple is a little two-roomed bungalow which probably served as the residence of the priest. Near these buildings an interesting discovery was a pitdwelling cut into the chalk to a depth of more than $10 \mathrm{ft}$. The sides curve towards the top and originally it was covered with a lid-like roof. The floors of rammed chalk were inserted at various periods and the pit would seem to have been inhabited in the later stages of its history. By the Roman period it was filled up. In cutting through a crossbank dividing off the eastern third of the fortress, in which the temple is situated, pottery and a quern of prehistoric date have been discovered, proving that the hill was occupied as a village before Maiden Castle at its earliest stage came into existence.

\section{Electric Shut-down in London on July 29}

A statement has now been issued by the Central Electricity Board on the failure of the supply in south-east and east England on Sunday, July 29. In this the Board refers to the joint report of the engineers of the C.E.B. and the London Power Company. The engineers state that they have explored every avenue which might elucidate the general failure, and in their opinion there is only one cause which could fully explain it. It must have been the breakdown of one of the turbines at the Deptford West Station of the London Power Company. The Board states that the system has always, even on Sunday loading, sufficient margin of plant in operation to make good immediately the loss of the largest station's output to the system, and it has also sufficient spare plant ready to be put into operation to maintain that margin against the unlikely contingency of a second station breaking down; but the Board had not considered what would happen if two major stations shut down simultaneously. The Sunday disposition of the generating plant had not allowed for this contingency. If such an abnormal event had happened on a week day, the arrangement of the plant is such that a widespread failure could have been avoided. The Board is satisfied that such a combination of untoward circumstances is not likely to recur and there need be no apprehension of any such general failure in the future.

\section{Statistics in Economic Planning}

IN Planning of July 17 (16 Queen Anne's Gate, Landon, S.W.1) emphasis is laid on the importance of settling economic and social problems, so far as possible, by reference to ascertained facts, rather than by the dim light of ancient tradition or with the aid of a flash of alleged inspiration. But if the fact-finding method is to prevail, certain conditions must be first satisfied. It is necessary to have a technique for collecting and publishing accurately and promptly the right information in the right form. Planning essentially consists of organising knowledge, and bringing it effectively to bear on current problems of economics, politics and sociology. Here is one of the most obvious contrasts between planning and laissez-faire. Laissez-faire assumed a process of automatic and almost unconscious growth. A few inquisitive persons, such as Bagehot, might occasionally inquire how the system worked, and which way it was going; but opinion on the whole was indifferent, if not hostile, to the gathering, publication and use of systematic facts and figures. The intense secrecy and suspicion still so often encountered when such information is required, is a survival of this prejudice. The forces now at work are tending to break down this obscurantism, so that one of the most notable features of the present time is the sudden growth of statistics and information services. In certain directions, however, necessary statistics have barely begun to be provided. There is no adequate index of the huge changes in the structure of society which have occurred in the past twenty years, and are still occurring under our eyes. Largescale planning demands a vast expansion of statistics and information services. Some expansion is taking place, but it is at present completely unco-ordinated, and there are immense gaps.

\section{Industrial and Agricultural Statistics}

THE Industrial and Agricultural Research Section of the Royal Statistical Society, formed by the Council in 1933, has just issued its first publication as a supplement to part 2, vol. 97 of the Journal of the Royal Statistical Society. The issue will be biannual (price 5s, each) and the second number will be published at the same time as part 4 of the current volume of the Journal. Some indication of the type of problem considered by the Section is obtained from the titles of the papers comprising the first number, which are as follows: "Application of Statistical Methods to Production and Research in Industry", "Statistics in Agricultural Research", "A New Method of Handling Statistical Data", and "Methods of Estimating from Samples the Population Standard Deviation". In addition, an account is given of the formation of the new section, and a bibliography of papers on agricultural statistics published during 1931-33 is included. The payment of an annual subseription of $10 \mathrm{~s}$. (excluding postage) secures both numbers of the supplement each year, and also confers the right to attend the meetings as an associate member of the Section. Orders and subscriptions should be addressed to the assistant secretary, Royal Statistical Society, 9 Adelphi Terrace, London, W.C.2, and marked I.A.R.S.

\section{Poland and Germany}

IT is not generally realised that Berlin was originally a Slav settlement. In vol. 18 of Nauka Polska (Warszawa : Imienia Mianowskiego) Dr. K. Piotrowicz, director of the Library of the Polish Academy 
of Sciences, gives a well-documented account of the manuscripts, documents, prints and other Polish works produced in early times on present German territory. It is clear that in the Middle Ages Polish culture played an important role in those lands now comprising eastern Germany, for many of the Polish kings and noblemen were patrons of learning. Also many scientific and other works by Polish authors were printed in towns as far west as Strasbourg. In the same volume there is an introductory note on the scientific and cultural relations between Germany and Poland by Prof. Aleksander Brückner, of the University of Berlin.

\section{Science in Poland}

Vor. 19 of Nauka Polska (issued simultaneously with vol. 18) contains articles on science in ancient times; problems in writing biographies; current scientific work at Lwów; the position of science in Italy, Greece, Rumania and Lithuania; and a full account of recent activities in England of the British Science Guild, the Association of Scientific Workers and the Parliamentary Science Committee. The volume concludes with a comprehensive international bibliography (20 pages) of "works concerning the psychology and sociology of science" for the years 1928-31. From Prof. T. Mańkowski's report on scientific and cultural life in Lwow at the present time it is clear that, in the faculties for pure science and medicine, modern equipment has been installed and everything is being done to encourage research workers and to see that they are not hampered by lack of facilities. Since the establishment of the Polish Republic, Lwów has become an increasingly important scientific centre in south-east Poland. A polytechnic and medical school existed before the War, but all cultural hife came to a standstill in 1914 and it was not until 1920 that circumstances were favourable for the re-establishment of a university in this city.

\section{Antarctic Exploration}

THe Penola, the vessel of Mr. J. Rymill's antarctic expedition, according to the Times of August 10, was commissioned at Southampton last week and carried out preliminary trials preparatory to sailing for London, where the stores and scientific instruments will be taken on board. The expedition's aeroplane, a three-seater De Havilland Fox Moth, about sixty tons of stores and some sixty Greenland dogs have already been sent out to the Falkland Islands by cargo-steamer. The Penola is due to leave London on September 2 for the Falkland Islands, calling on the way at Monte Video. The staff of the expedition will themselves constitute the crew under command of Lieut. R. E. D. Ryder, R.N. The Penola is a three-masted topsail schooner with two 50 H.P. Diesel engines. Most of the members of the expedition have already had arctic or antarctic experience. While the work will be primarily exploratory, attention will be paid to various scientific problems including plankton, the occurrence of 'heavy water', the sociology of penguins and meteoro- logical work. It is hoped to trace the southern extensions of the Antarctic Andes which are known as the Graham Land islands. Although the expedition hopes to be away for more than two years, the total cost is not expected to exceed $£ 15,000$, which is considerably lower than that of any other previous expedition. There is also news of Admiral Byrd's antarctic expedition; Admiral Byrd himself has been living alone at an observation hut some 120 miles south of his base camp in the Bay of Whales in order to secure continuous meteorological records. He had recently asked to be relieved owing to illness, and a rescue party succeeded in reaching him on August 13.

\section{American Trans-Antarctic Flight}

THE original plan of the Ellsworth Antarctic Expedition for a flight across Antarctica from the Ross Sea to the Weddell Sea and back to the base had to be abandoned last January owing to serious damage to the aeroplane on the pack-ice. Mr. Ellsworth now proposes new plans for the southern summer of 1934-35, and explains them at length in Natural History of July-August 1934. His ship, Wyatt Earp, will reach Deception Island about November 1. From there, Messrs. Ellsworth and Balchen propose to fly southward along the unknown western edge of the Weddell Sea to the ice-barrier at its head and then straight across Antarctica to the Bay of Whales on the Ross Sea, a total distance of 2,800 miles over virtually unexplored areas. The ship will go round to the Ross Sea to pick up the expedition, which will no doubt have the use of Byrd's base in the Bay of Whales. The plane has a maximum speed of 210 miles an hour, and it is proposed to fly at 150 miles an hour. Fully loaded, with pontoons in place of ski, its cruising radius is 3,200 miles. The use of pontoons, which materially increases the weight, is necessary because Deception Island does not offer a land surface sufficiently extensive for a 'take off' for this heavy machine.

\section{American Indian Land-Tenure}

A Movement has been initiated in the United States for the reform of the terms of land-tenure among the Indians. Under the law of 1887 , lands were allotted to the Indians on individual tenure, a system of which they had had no experience under tribal institutions. No sooner had allotment been made than land dealers began to acquire holdings from the Indians, in many instances in exchange for a few bottles of whisky or other articles of little or no value. It is estimated that in less than fifty years the Indians have lost two thirds of their lands, and whole tribes have been reduced to pauperism. A conference has been summoned, it is announced by Science Service, Washington, to discuss this situation, as well as other problems affecting the Indians. It will be attended by representatives of the Indian Rights Association, the National Association on Indian Affairs and many other bodies interested in the welfare of the Indian. The Commissioner of Indian Affairs, Mr. John Collier, will also attend. Special attention will be given to drafting proposals 